\title{
KINETICS OF CAROTENOID DEGRADATION IN SPICE PAPRIKA AS AFFECTED BY STORAGE TEMPERATURE AND SEED ADDITION
}

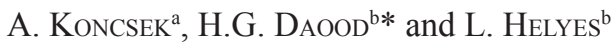 \\ ${ }^{a}$ Rubin Spice Paprika Processing Szeged Ltd., H-6771 Szeged-Szőreg, Szerb u. 173. Hungary \\ bSzent István University, H-2103 Gödöllö, Páter K. u. 1. Hungary \\ (Received: 4 September 2015; accepted: 21 March 2016)
}

The extractable (ASTA) colour retention of four different milled spice paprikas was evaluated at 10, 20, 35, 50, and $60{ }^{\circ} \mathrm{C}$ storage temperature. The ASTA colour stability during long-term storage period strongly depended on the temperature, primary handling and drying of the fresh crop, and the applied production technology. The cooled (10 $\left.{ }^{\circ} \mathrm{C}\right)$ or temperature-controlled $\left(20^{\circ} \mathrm{C}\right)$ conditions appeared to be a reasonable solution to preserve the quality of paprika powder. The kinetics study on the temperature dependence of ASTA colour loss estimated the apparent reaction order, rate constants, predicted half-life times and activation energy. The $\mathrm{Q}_{10}$ approach and shelf life-plot resulted in useful data, which can be suitable for quick and economical evaluation of further spice paprika products.

Keywords: paprika, storage, carotenoids, antioxidants, kinetics

Spice paprika (Capsicum annuum L.) is one of the most important traditional crops in Hungary (MÁRKus \& KAPITÁNY, 2001). Its dried and ground product (paprika) is a widely used natural food colour and flavour. The colour of ripe fruit of red pepper is due to the high concentration of fat-soluble carotenoid-type pigment (Somos, 1984).

In the spice paprika products, colour is considered the main quality factor, which determines their commercial value. It is a serious problem that ground paprika loses its colour during storage via pigment oxidation. Pigment degradation is further accelerated upon exposure to heat and/or to light. The colour stability of ground spice paprika during technological process and storage has been found to be affected by the level of antioxidants such as ascorbic acid and tocopherols before processing (DAOOD et al., 1996; MÁrKus et al., 1999). In studies by BIACS and co-workers (1992) and DAOOD and co-workers (1996) it has been demonstrated that the concentration of both antioxidants should be kept at the concentration at which they effectively function as oxidation barriers against oxidation of carotenoids in ground paprika.

Studies by MALChev and co-workers (1982), CARBOnell and co-workers (1986), and Minguez-Mosquera and Honero-Méndez (1993, 1994a, b) indicated that the technological factors most likely to affect quality and colour stability of paprika products may include overripening, drying parameters, milling, and storage conditions.

Because this work deals with imported and Hungarian types of paprika produced under different cultivation and processing conditions, it is of interest to investigate their storage stability, which is expected to differ considerably. In addition, it is important to search how the grinding of seeds or addition of more seeds modifies the storage stability of the two paprika types.

\footnotetext{
* To whom correspondence should be addressed. Phone:+36-70-3156473; fax: +36-28-410804; e-mail: hdaood682@gmail.com
} 
The objectives of this study were to evaluate the effect of storage temperatures on paprika colour degradation, to estimate the Arrhenius kinetic parameters, calculate the parameters of the accelerated shelf life testing for colour loss prediction, and to study the effect of seed addition on the kinetics of colour loss in home-cultivated and imported spice paprika.

\section{Materials and methods}

\subsection{Materials}

The industrial thermal dehydration of over-ripened Szegedi-80 spice paprika cultivar pods was carried out by Binder industrial drying unit(HGI 18F 86105, Hans Binder Maschinenfabrik, Germany, 1986), which consisted of washing equipments, chopper, and the drying equipment.

Chinese sun-dried paprika batch was purchased from spice paprika production area (Qingdao, China), where the harvest of spice red pepper usually starts when the senescence of the pods begins on bushes (wrinkled, deep red pods). Sun drying took approximately 40 days before shipping. Four types of ground paprika were produced:

Sorted Szegedi- 80 paprika, where the greatest part of the stems and seeds were removed from the dried pods with the help of industrial sorting sieving machine (abbreviation: Sorted Sz80)

Szegedi-80 paprika, where the dried paprika fruit are milled together with their own seed (18-20\%) and stem (abbreviation: Sz80)

Sun-dried paprika, where the dried imported paprika pods are milled together with their own seed (22\%) and stem (abbreviation: Sun-dried)

Sun-dried paprika + paprika seeds, where the dried whole paprika pods are milled together with 15\% additional paprika seeds (abbreviation: Sun-dried + seeds).

The dry spice paprika lots were processed in a pilot plant including coarse grinding with hammer mill (Europemil H500-950, Skjold Maskinfabrikken BC., Denmark) followed by fine milling using traditional stone mills (Own construction of Rubin Ltd., 1996). Approximately $100 \mathrm{~kg}$ of each sample were milled. Between the samples, the equipment was run on empty status for $20 \mathrm{~min}$, then the first $40-50 \mathrm{~kg}$ of the next sample was discarded. The spice paprika powder was passed through a screen that allowed particles with a size of 450 $\mu \mathrm{m}$ to pass through and the larger particles were sent back for re-milling in a closed system. The fine powders were packaged in opaque nylon sacks with $0.08 \mathrm{~mm}$ thickness (Propolip Ltd. Szeged, Hungary) and stored in a cold store at around $10{ }^{\circ} \mathrm{C}$.

\subsection{Storage experimental design}

From each paprika powder lots, amounts of $300 \mathrm{~g}$ (in triplicates for any storage condition) were packed in commercially available double Cellophane bags (low permeability to water, air, and oils). The samples were stored in temperature-controlled dark cabinets (PLP 302, PLP 403, LaborMIM LP301) at $60{ }^{\circ} \mathrm{C}, 50{ }^{\circ} \mathrm{C}, 35^{\circ} \mathrm{C}, 20^{\circ} \mathrm{C}$, and $10^{\circ} \mathrm{C}$ for 12 months. The temperatures were monitored by a calibrated digital thermometer (Dostmann P300W). Samples were taken daily, every two weeks, or monthly, depending on storage temperature, for colour measurement. Before sampling, the paprika powders were mixed thoroughly in a blender for $20 \mathrm{sec}$. 


\subsection{Extractable colour (ASTA) test}

The extractable colour of paprika powder samples were measured according to the standard ASTA (1997) method (Hungarian STANDARd, 2010). Paprika powder samples of 0.0700$0.0900 \mathrm{~g}$ were measured and transferred into $100 \mathrm{ml}$ volumetric flasks. The volume was adjusted with acetone, and after 4 hours in the dark, the absorbance of the extract was measured at $460 \mathrm{~nm}$ against an acetone blank. ASTA unit was calculated according to the formula:

$$
\text { ASTA }=\frac{\text { Absorbance } \times 16.4 \times \text { factor }}{\text { the weight of sample }(\mathrm{g})},
$$

where the factor $=0.315 /$ absorbance of the standard colour solution. Three replicates were conducted for each measurement.

\subsection{Data analysis}

Principles of chemical kinetics and accelerated shelf life testing (ASLT) were applied to evaluate the extractable colour loss of paprika. Generally, the rate of food quality change $(\mathrm{dQ} / \mathrm{dt})$ can be expressed as a function of composition $\left(\mathrm{C}_{\mathrm{i}}\right)$ and environmental factors $\left(\mathrm{E}_{\mathrm{j}}\right)$ (SAGuY \& Karel, 1980):

$$
\frac{d Q}{d t}=F\left(C_{i}, E_{j}\right)
$$

The integrated formulas for zero-, first- and second order kinetic models are the followings:

$$
\begin{aligned}
& \text { Zero-order: }[A]=-k \cdot t+\left[A_{o}\right] \text { Half-life time: } t_{1 / 2}=\frac{\left[A_{0}\right]}{2 k} \\
& \text { First-order: } \ln \frac{[A]}{\left[A_{0}\right]}=-k \cdot t \text { Half-life time: } t_{1 / 2}=\frac{\ln 2}{k} \\
& \text { Second-order: } \frac{1}{[A]}-\frac{1}{\left[A_{0}\right]}=k \cdot t \text { Half-life time: } t_{1 / 2}=\frac{1}{k \cdot\left[A_{0}\right]}
\end{aligned}
$$

The Arrhenius equation is a widely used model to describe the reaction rate constant temperature dependence:

$$
k=k_{A} \exp \left(-\frac{E_{A}}{R T}\right),
$$

where $\mathrm{k}_{\mathrm{A}}$ is the Arrhenius equation constant, $\mathrm{E}_{\mathrm{A}}$ is the activation energy.

$\mathrm{Q}_{10}$ describes the temperature dependence of a reaction, as the ratio of the reaction rate (k) constants at temperatures differing by $10^{\circ} \mathrm{C}$ or the change of shelf life $\theta_{\mathrm{s}}$ when the food is stored at a temperature higher by $10^{\circ} \mathrm{C}$ (ROBERTSON, 2007):

$$
Q_{10}=\frac{k_{T+10}}{k_{T}}=\frac{\Theta_{S_{T}}}{\Theta_{S_{T+10}}}
$$


The $\mathrm{Q}_{10}$ approach is derived directly from Arrhenius equation:

$$
Q_{10}=e^{10 b}, b=\frac{E_{A}}{R(T)(T+10)},
$$

When $\ln \theta$ is plotted vs. temperature $(1 / \mathrm{T})$, the shelf life plot is obtained.

Statistical analysis and kinetics computations were performed with the help of Microsoft Excel and Statistica 8 software (version 8.0.360.0, StatSoft Inc., 2007). The Shapiro-Wilk test was used for checking the normal distribution, and Levene's test for the homogeneity of variance. ANOVA followed by post-hoc (Fisher's test) was applied for the detailed evaluation of experimental data. Linear regression and its statistical evaluations were used for the estimation of kinetic and accelerated shelf-life test parameters.

\section{Results and discussion}

Traditionally, the dried spice paprika is stored under ambient warehouse or shop condition, in closed bags or in other packages, which have to be able to protect the product from light, retard aroma loss and water absorption. Generally, as spices are "non-perishable" foods, the "ambient condition" means that the storage should be at room temperature or below. Storage at $35{ }^{\circ} \mathrm{C}$ is of practical importance, because it is applicable in natural storage, particularly in summer time.

The ASTA colour value of seed-containing paprikas was significantly lower $(\mathrm{P}<0.05)$ than that of seed-non-containing sorted Sz80, due to the dilution effect of seeds.

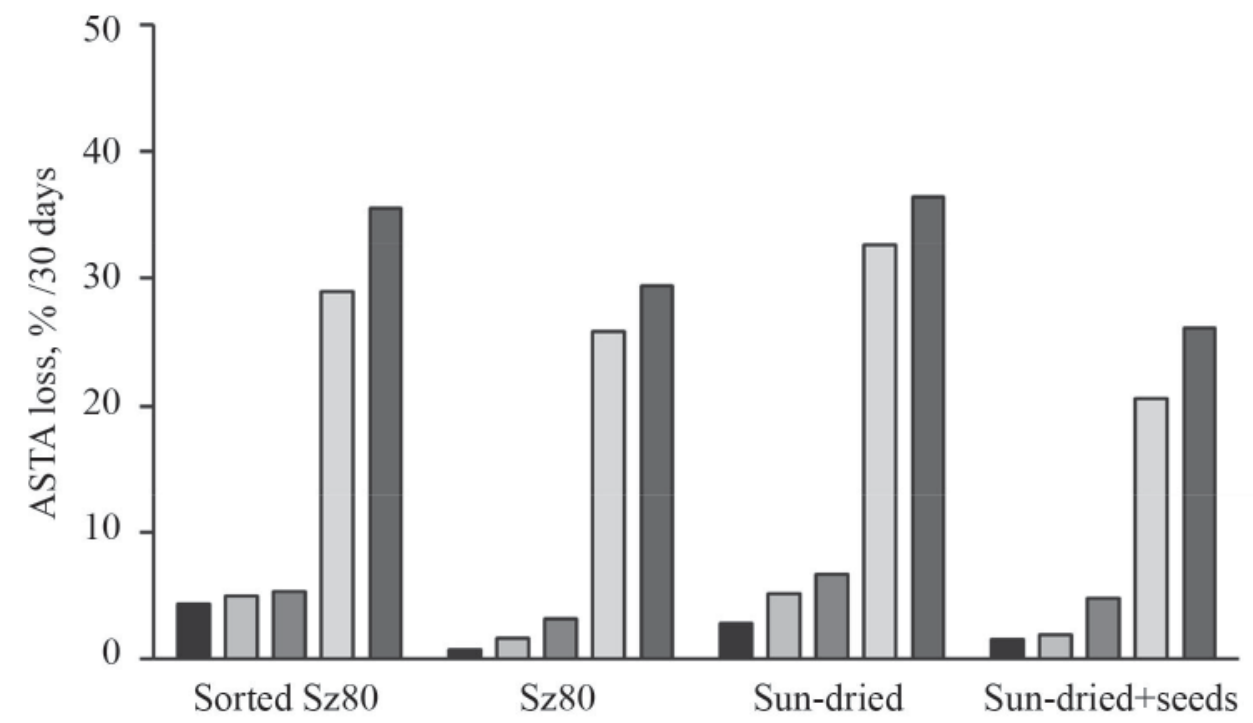

Fig. 1. Colour loss (ASTA) after 30 days of storage ㅁ: $10^{\circ} \mathrm{C} ; \square: 20^{\circ} \mathrm{C} ; \square: 35^{\circ} \mathrm{C} ; \square: 50^{\circ} \mathrm{C} ; \square: 60^{\circ} \mathrm{C}$ 
Figure 1 shows that the magnitude of the colour loss is strongly influenced by the storage temperatures with seed-containing samples being of higher stability than seed-non-containing sample at all storage periods. Since the rate of colour loss was high at higher temperature, the storage at $50-60{ }^{\circ} \mathrm{C}$ was only for 1 month.

Table 1. Changes in ASTA value of paprika products as a function of storage time and temperature

\begin{tabular}{|c|c|c|c|c|}
\hline \multirow{2}{*}{$\begin{array}{l}\text { Storage time } \\
\text { (day)/ } \\
\text { temp. }\left({ }^{\circ} \mathrm{C}\right)\end{array}$} & \multicolumn{4}{|c|}{ Paprika products } \\
\hline & Sorted Sz80 & Sz80 & Sun-dried & Sun-dried + seed \\
\hline \multicolumn{5}{|l|}{$10^{\circ} \mathrm{C}^{*}$} \\
\hline 0 day & $205.2 \pm 2.85(0)$ & $179.3 \pm 2.48(0)$ & $167.6 \pm 1.85(0)$ & $140.4 \pm 2.84(0)$ \\
\hline 90 days & $194.9 \pm 0.35(10.3)$ & $174.2 \pm 0.45(5.1)$ & $147.3 \pm 1.75(20.3)$ & $137.5 \pm 1.39(3.4)$ \\
\hline 180 days & $178.0 \pm 0.77(17.3)$ & $170.4 \pm 1.01(8.9)$ & $140.5 \pm 1.67(27.1)$ & $123.6 \pm 0.64((16.8)$ \\
\hline 365 days & $155.8 \pm 1.62(49.4)$ & $145.8 \pm 1.05(33.5)$ & $114.4 \pm 0.84(53.2)$ & $108.7 \pm 0.45(31.7)$ \\
\hline \multicolumn{5}{|l|}{$20^{\circ} \mathrm{C}^{*}$} \\
\hline 0 day & $205.2 \pm 2.85(0)$ & $179.3 \pm 2.48(0)$ & $167.6 \pm 1.85(0)$ & $140.4 \pm 2.84(0)$ \\
\hline 90 days & $189.6 \pm 1.91(15.6)$ & $169.9 \pm 1.59(9.4)$ & $146.2 \pm 0.6(21.4)$ & $132.8 \pm 1.38(7.6)$ \\
\hline 180 days & $160.1 \pm 1.13(45.0)$ & $143.2 \pm 1.78(36.1)$ & $124.1 \pm 0.26(43.5)$ & $123.1 \pm 1.67(17.3)$ \\
\hline 365 days & $128.0 \pm 1.12(77.2)$ & $107.5 \pm 0.80(71.8)$ & $87.3 \pm 0.62(80.6)$ & $97.2 \pm 1.11(43.2)$ \\
\hline \multicolumn{5}{|l|}{$35^{\circ} \mathrm{C}^{* *}$} \\
\hline 0 day & $205.2 \pm 2.85(0)$ & $179.3 \pm 2.48(0)$ & $167.6 \pm 1.85(0)$ & $140.4 \pm 2.84(0)$ \\
\hline 30 days & $184.1 \pm 2.02(21.1)$ & $166.7 \pm 2.74(12.6)$ & $146.4 \pm 2.31(21.2)$ & $122.0 \pm 0.67(18.4)$ \\
\hline 90 days & $135.3 \pm 2.16(69.9)$ & $134.2 \pm 1.29(45.1)$ & $106.9 \pm 1.06(60.7)$ & $108.3 \pm 0.93(32.1)$ \\
\hline 180 days & $99.3 \pm 0.67(105.9)$ & $109.3 \pm 0.81(70.0)$ & $78.3 \pm 0.89(89.3)$ & $85.4 \pm 0.94(55.0)$ \\
\hline \multicolumn{5}{|l|}{$50{ }^{\circ} \mathrm{C}^{* * *}$} \\
\hline 0 day & $205.2 \pm 2.85(0)$ & $179.3 \pm 2.48(0)$ & $167.6 \pm 1.85(0)$ & $140.4 \pm 2.84(0)$ \\
\hline 10 days & $181.4 \pm 1.46(23.8)$ & $162.2 \pm 2.54(17.1)$ & $146.5 \pm 0.44(21.1)$ & $127.3 \pm 0.71(13.1)$ \\
\hline 20 days & $161.7 \pm 0.38(43.3)$ & $146.9 \pm 2.12(32.4)$ & $127.7 \pm 0.91(39.9)$ & $120.8 \pm 0.31(19.6)$ \\
\hline 30 days & $145.8 \pm 0.45(59.4)$ & $133.1 \pm 0.24(46.2)$ & $113.0 \pm 2.20(45.6)$ & $111.5 \pm 1.60(28.9)$ \\
\hline \multicolumn{5}{|l|}{$60^{\circ} \mathrm{C}^{* * *}$} \\
\hline 0 day & $205.2 \pm 2.85(0)$ & $179.3 \pm 2.48(0)$ & $167.6 \pm 1.85(0)$ & $140.4 \pm 2.84(0)$ \\
\hline 10 days & $156.2 \pm 0.79(49.0)$ & $175.1 \pm 1.28(42.0)$ & $140.3 \pm 0.33(27.3)$ & $125.8 \pm 1.25(14.6)$ \\
\hline 20 days & $150.3 \pm 0.51(54.9)$ & $139.6 \pm 0.76(39.7)$ & $120.2 \pm 1.16(47.4)$ & $114.5 \pm 0.08(25.9)$ \\
\hline 30 days & $132.3 \pm 0.18(72.9)$ & $126.6 \pm 0.14(52.7)$ & $106.6 \pm 0.69(61.0)$ & $103.8 \pm 2.10(36.6)$ \\
\hline
\end{tabular}

Measurement frequencies: *monthly; **two weeks; ***daily. In brackets: lost ASTA values

As shown in Table 1, the imported paprika, which contains $37 \%$ seed, had better stability toward oxidative degradation at most of the storage temperatures applied. The favourable effect of seed on stability of pigments in the product from Hungarian Sz80 was evident, while imported paprika needed seed proportion higher than $22 \%$ to improve its colour stability. This may be linked to the low level of vitamin $\mathrm{C}$ in imported paprika, in which vitamin $\mathrm{C}$ content was undetectable (Table 2). In such case, the high content of the chemically active $\gamma$-tocopherol $\left(133.2 \mu \mathrm{g} \mathrm{g}^{-1}\right)$ derived from the additional amount of seeds can compensate vitamin $\mathrm{C}$ in the antioxidant defence of the powders. 
Table 2. The initial antioxidant content of spice paprika samples determined by HPLC

\begin{tabular}{lccc}
\hline Paprika samples & Ascorbic acid $\left(\mu \mathrm{g} \mathrm{g}^{-1}\right) \pm \mathrm{SD}$ & $\alpha$-Tocopherol $\left(\mu \mathrm{g} \mathrm{g}^{-1}\right) \pm \mathrm{SD}$ & $\gamma$-Tocopherol $\left(\mu \mathrm{g} \mathrm{g}^{-1}\right) \pm \mathrm{SD}^{-}$ \\
\hline Sorted Sz80 & $2384.3 \pm 3.4$ & $550.8 \pm 3.4$ & $12.3 \pm 2.2$ \\
Sz80 & $2028.5 \pm 4.1$ & $442.6 \pm 2.2$ & $45.1 \pm 1.5$ \\
Sun-dried & nd & $364.4 \pm 1.8$ & $49.6 \pm 1.6$ \\
Sun-dried+seeds & nd & $251.3 \pm 2.6$ & $133.2 \pm 3.2$ \\
\hline
\end{tabular}

Analysis of ascorbic acid and tocopherol was carried out according to DAOOD and co-workers (1996) nd: not detected

When Sz80 is compared with imported sun-dried sample (almost have close seed\%) it is clear that home-produced product is much more stable $(\mathrm{P}>0.05)$ than the imported sundried product, most probably due to the high level of initial vitamin C, which was $2028 \mu \mathrm{g} \mathrm{g}^{-1}$ for Sz80 and 2384 for sorted Sz80. The value of lost ASTA increased from 10.3 to 17.3, from 15.6 to 45.0 , and from 69.9 to 105.9 when the storage time increased from 3 to 6 months at temperature 10,20 , and $35^{\circ} \mathrm{C}$, respectively.

With advance in storage at $10-35^{\circ} \mathrm{C}$ and in all periods at $50-60{ }^{\circ} \mathrm{C}$, the highest ASTA loss was recorded for sorted Sz80, most probably due to destruction of vitamin $\mathrm{C}$, the major antioxidant in such product, to a high extent. Therefore, grinding the seeds with the skin is necessary to reduce colour loss during storage for a period longer than 90 days. These findings agree with the findings of DAOOD and co-workers (1996) and MÁRKUs and co-workers (1999) that the oil and $\gamma$-tocopherol derived from seeds are essential elements in the colour stability of spice paprika. Furthermore, DAOOD and co-workers (1996) found that the levels of ascorbic acid and tocopherols are low in naturally dried paprika, and grinding the seeds with the dried peel is necessary to increase storage stability of paprika products.

A two-step method was applied to estimate the Arrhenius parameters. The first is the regression of quality function and the second is the regression of $\ln (\mathrm{k}) \mathrm{vs} .1 / \mathrm{T}$. The apparent reaction rate constants $(\mathrm{k})$, reaction order, and estimated initial concentrations $\left(\mathrm{A}_{0}\right)$ were determined by linear regression of quality functions ([A] for zero order, $\ln [\mathrm{A}] /\left[\mathrm{A}_{0}\right]$ for first order, and $1 /[\mathrm{A}]-1 /\left[\mathrm{A}_{0}\right]$ for second order reaction versus time) at each storage temperature. The $\mathrm{R}^{2}$ is in most cases sufficient criterion in deciding the appropriate reaction order, however, increasing the order of a model tends to give higher $\mathrm{R}^{2}$, thus further statistical analysis is advised by BOYLE and co-workers (1974) and LABUZA and KAMMAN (1983) evaluating the rate constant and the goodness of fit of model.

Under all storage conditions, the ASTA colour loss was found to be described by apparent second order reaction. The kinetic parameters (rate constants, half-life times) are summarized in Table 3. Beside the closing to unity of $\mathrm{R}^{2}$, adjusted $\mathrm{R}^{2}$, the results of $\mathrm{F}$ test (ANOVA, $\mathrm{P}<0.05$ ) and residual analysis were taken into consideration to decide the kinetic parameters. In addition to calculating $95 \%$ confidence limits of kinetic parameters (using the Student $t$ distribution), the standardized residuals evaluation showed random distribution around zero within -2 and +2 as recommended by TAOUKIS and co-workers (1997). The estimation of $A_{0}$ provided additional criterion of adequacy of applied model. The half-life time $\left(t_{1 / 2}\right)$ was calculated according to the second order equations (5) using the lower and upper confidence limit of rate constant $(\mathrm{k})$ and initial colour value $\left(\mathrm{A}_{0}\right)$. 
Table 3. Second order kinetic parameters $( \pm 95.00 \%$ Cnf.Lmt $)$

\begin{tabular}{|c|c|c|c|c|c|}
\hline Samples & Temp. $\left(C^{o}\right)$ & $\mathrm{C}_{0}$ (ASTA) & $\mathrm{k}\left(\mathrm{ASTA}^{-1}\right.$ days $\left.^{-1}\right) \times 10^{-5}$ & $\mathrm{t}_{1 / 2}$ (days) & Adj. $R^{2}$ \\
\hline \multirow[t]{5}{*}{ Sorted Sz80 } & 10 & $202.1 \pm 2.2$ & $0.457 \pm 0.0328^{\mathrm{a}^{*}}$ & $1082 \pm 83.5^{\mathrm{a}}$ & 0.954 \\
\hline & 20 & $199.0 \pm 3.4$ & $1.061 \pm 0.0718^{\mathrm{b}}$ & $525 \pm 43.1^{\mathrm{b}}$ & 0.974 \\
\hline & 35 & $197.0 \pm 3.5$ & $3.018 \pm 0.1169^{\mathrm{c}}$ & $168 \pm 9.1^{\mathrm{c}}$ & 0.986 \\
\hline & 50 & $200.4 \pm 0.9$ & $6.595 \pm 0.2260^{\mathrm{d}}$ & $76 \pm 2.9^{\mathrm{d}}$ & 0.982 \\
\hline & 60 & $199.0 \pm 1.3$ & $9.020 \pm 0.2462^{\mathrm{e}}$ & $56 \pm 1.8^{\mathrm{e}}$ & 0.989 \\
\hline \multirow[t]{5}{*}{$\mathrm{Sz} 80$} & 10 & $184.3 \pm 1.5$ & $0.433 \pm 0.0350^{\mathrm{a}}$ & $1254 \pm 103.7^{\mathrm{f}}$ & 0.943 \\
\hline & 20 & $179.4 \pm 3.6$ & $0.831 \pm 0.0463^{b}$ & $604 \pm 41.7^{\mathrm{g}}$ & 0.959 \\
\hline & 35 & $175.6 \pm 2.0$ & $2.044 \pm 0.0817^{\mathrm{f}}$ & $279 \pm 13.8^{\mathrm{h}}$ & 0.985 \\
\hline & 50 & $178.0 \pm 0.9$ & $6.545 \pm 0.2626^{\mathrm{d}}$ & $86 \pm 3.7^{\mathrm{d}}$ & 0.976 \\
\hline & 60 & $172.6 \pm 0.9$ & $7.311 \pm 0.2321^{\mathrm{h}}$ & $79 \pm 2.9^{\mathrm{i}}$ & 0.985 \\
\hline \multirow[t]{5}{*}{ Sun-dried } & 10 & $163.8 \pm 1.7$ & $0.785 \pm 0.0392^{\mathrm{i}}$ & $778 \pm 44.8^{\mathrm{j}}$ & 0.979 \\
\hline & 20 & $161.9 \pm 3.1$ & $1.534 \pm 0.0709^{j}$ & $403 \pm 25.0^{\mathrm{k}}$ & 0.982 \\
\hline & 35 & $156.2 \pm 3.1$ & $3.712 \pm 0.1305^{\mathrm{k}}$ & $172 \pm 9.1^{\mathrm{c}}$ & 0.989 \\
\hline & 50 & $164.1 \pm 1.0$ & $9.556 \pm 0.3313^{1}$ & $64 \pm 2.5^{\mathrm{d}}$ & 0.982 \\
\hline & 60 & $159.0 \pm 1.2$ & $11.131 \pm 0.2977^{\mathrm{m}}$ & $56 \pm 1.9^{\mathrm{e}}$ & 0.989 \\
\hline \multirow[t]{5}{*}{ Sun-dried + seeds } & 10 & $143.3 \pm 1.9$ & $0.636 \pm 0.0670^{\mathrm{a}}$ & $1096 \pm 117.9^{\mathrm{a}}$ & 0.914 \\
\hline & 20 & $142.2 \pm 1.2$ & $0.972 \pm 0.0625^{\mathrm{b}}$ & $723 \pm 49.5^{1}$ & 0.966 \\
\hline & 35 & $134.6 \pm 1.6$ & $2.558 \pm 0.1742^{\mathrm{n}}$ & $290 \pm 21.9^{\mathrm{h}}$ & 0.959 \\
\hline & 50 & $137.8 \pm 0.6$ & $5.456 \pm 0.3710^{\circ}$ & $133 \pm 9.1^{\mathrm{m}}$ & 0.933 \\
\hline & 60 & $134.8 \pm 0.9$ & $7.265 \pm 0.4480^{\mathrm{h}}$ & $102 \pm 6.6^{\mathrm{n}}$ & 0.944 \\
\hline
\end{tabular}

* The same letters indicate no significant difference $(\mathrm{P}>0.05)$ between the samples at the same storage temperature.

Kinetic parameters of colour loss in spice paprika samples (Table 3) confirmed the harmful effect of increasing storage temperature, since the decreasing half-life time $\left(\mathrm{t}_{1 / 2}\right)$ and increasing rate constant $(\mathrm{k})$ indicate the accelerated decomposition of natural colour content. The half-life time $\left(\mathrm{t}_{1 / 2}\right)$ and rate constant $(\mathrm{k})$ enabled the transparent comparisons of colour retention properties depending on the primary and the processing methods.

The significant differences $(\mathrm{P}<0.05)$ in the half-life times of paprika samples at different temperatures were evident. Post-hoc test revealed similar $(\mathrm{P}>0.05)$ half times of sorted Sz80 paprika and sun-dried + seed sample at $10{ }^{\circ} \mathrm{C}$, while the longest time was found in Sz80 paprika and the shortest in sun-dried one. At $35^{\circ} \mathrm{C}, 50^{\circ} \mathrm{C}$, and $60^{\circ} \mathrm{C}$ there were no differences in the half-life times of sorted Sz80 paprika and sun-dried paprika, confirming their higher sensitivity to high storage temperature.

Using the Arrhenius relationship and plotting $\ln \mathrm{k}$ against the reciprocal absolute temperature, 1/T, a straight line was obtained with a slope of $-\mathrm{E}_{\mathrm{A}} / \mathrm{R}$. As indicated in Figure 2, the reaction with a higher $\mathrm{E}_{\mathrm{A}}$ has a steeper slope; the reaction rate is thus very sensitive to temperature change. In contrast, the reaction with a lower $\mathrm{E}_{\mathrm{A}}$ is less sensitive to a temperature change (slope of sorted Sz80: 5884.6, Sz80: 5457.2, sun-dried: 5221.3, sun-dried + seeds: 4819.3). 


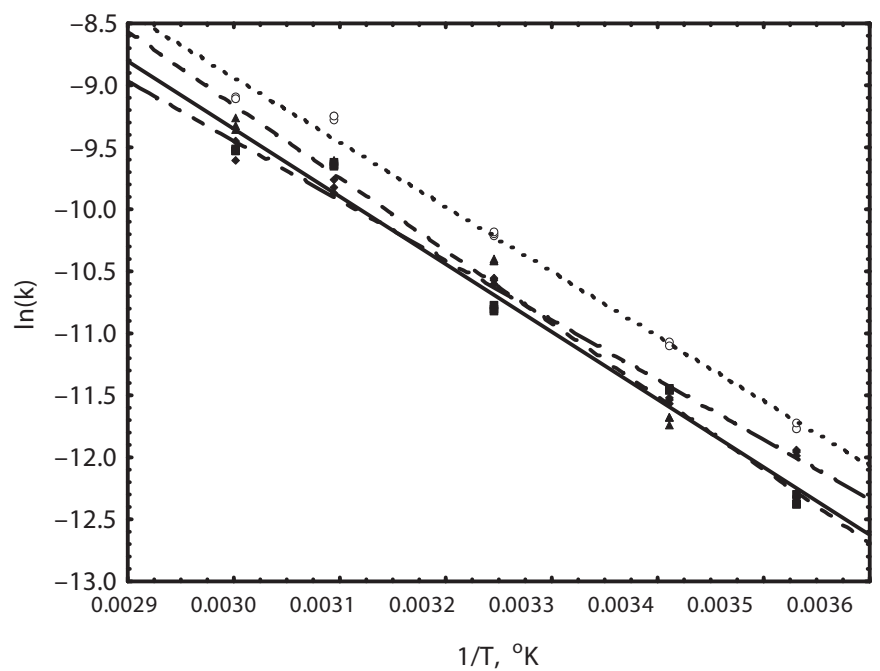

Fig. 2. Arrhenius plot for colour change during storage of different paprika samples - - -: Sorted Sz80; __ : Sz80; ...... Sun-dried; -_..-.-: Sun-dried+seeds

Comparing the $\mathrm{E}_{\mathrm{A}}$ of different samples the post-hoc test indicated significant difference $(\mathrm{P}>0.05)$ between sorted Sz80 and sun-dried + seeds samples, most probably due to high oil and $\gamma$-tocopherol level in seed-containing paprika. The high proportion of seeds might cause the slightly different $\mathrm{E}_{\mathrm{A}}$, because the activation energy is very specific for each system, as stated by LABUZA (1984).

Table 4. Activation energies and $\mathrm{Q}_{10}$ values $( \pm 95.00 \%$ Cnf.Lmt $)$

\begin{tabular}{lccccc}
\multicolumn{5}{c}{ Table 4. Activation energies and $\mathrm{Q}_{10}$ values $( \pm 95.00 \%$ Cnf.Lmt $)$} \\
\hline Samples & $\mathrm{E}_{\mathrm{A}}(\mathrm{kJ} / \mathrm{mol})$ & $\begin{array}{c}\operatorname{lnk}_{0} \\
\left(\mathrm{ASTA}^{-1} \mathrm{days}^{-1}\right)\end{array}$ & Adj. $\mathrm{R}^{2}$ & $\mathrm{Q}_{10}$ & Adj. $^{2}$ \\
\hline Sorted Sz80 & $48.92 \pm 3.284^{\mathrm{a}^{*}}$ & $8.496 \pm 1.288$ & 0.987 & $2.000 \pm 0.0546^{\mathrm{a}}$ & 0.850 \\
Sz80 & $45.37 \pm 4.026^{\mathrm{a}}$ & $7.021 \pm 1.580$ & 0.977 & $1.830 \pm 0.0660^{\mathrm{b}}$ & 0.976 \\
Sun-dried & $43.41 \pm 2.756^{\mathrm{a}}$ & $6.725 \pm 1.082$ & 0.988 & $1.848 \pm 0.0367^{\mathrm{b}}$ & 0.943 \\
Sun-dried+seeds & $40.06 \pm 2.203^{\mathrm{b}}$ & $5.010 \pm 0.865$ & 0.991 & $1.758 \pm 0.0000^{\mathrm{c}}$ & 0.910 \\
\hline
\end{tabular}

* The same letters indicate no significant difference $(\mathrm{P}>0.05)$

The $\mathrm{Q}_{10}$ approach can be used instead of the activation energy concept, and in most of the studies, it is applied at rather narrow $\left(20-30^{\circ} \mathrm{C}\right)$ temperature range (LABUZA, 1984), (Table 4). The parameters confirmed that $\mathrm{Q}_{10}$ on narrow temperature interval gives the best approach for the shelf life predictions (Fig. 3). 


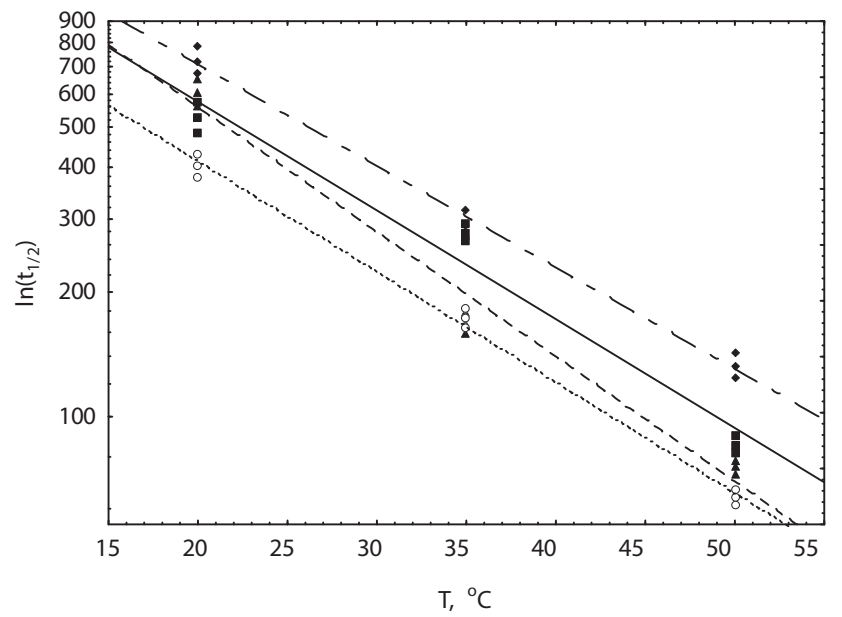

Fig. 3. Shelf life plot for different paprika samples stored at different temperatures - - - : Sorted Sz80; ——: Sz80; ......: Sun-dried; ._.....: Sun-dried+seeds

\section{Conclusions}

It can be concluded that storage of paprika at $10-20^{\circ} \mathrm{C}$ is required to preserve the quality and commercial value of the product. To make a product from imported sun-dried pepper with reduced colour loss, it is essentially needed to supply it with extra amounts of natural antioxidants. Additional amount of $\gamma$-tocopherol via increase of seed proportion to $37 \%$ seems to be a good alternative. Kinetics study on the temperature dependence of ASTA colour stability of spice paprika produced useful data, which enables the relative quick and economical evaluation and comparison of different spice paprika products.

This work was supported by the Rubin Spice Paprika Processing Szeged Ltd. and Research Centre of Excellence-9878/2015/FEKUT and KTIA_AIK_12-1-2012-0012 projects.

\section{References}

ASTA (American Sice Trade Association) (1997): Extractable colour in capsicums and their oleoresins. Method no. 20.1. Official analytical methods of the American Spice Trade Association. $4^{\text {th }}$ ed., pp. 89-104.

Biacs, P.A., Czinkotai, B. \& HoschKe, A. (1992): Factors affecting stability of colored substances in paprika powders. J. Agr. Food Chem., 40, 363-367.

Boyle, W.C., Berthouex, P.M. \& Rooney, T.C. (1974): Pitfalls in parameter estimation for oxygen transfer data. J. Environ. Eng. - ASCE, 100, 391-408.

Carbonell, J.V., Pinaga, F., Yusa, V. \& Pena, J.L. (1986): The dehydration of paprika with ambient and heated air and the kinetics of color degradation during storage. J. Food Eng., 5, 179-193.

Daood, H.G., Vinkler, M., Markus, F., Hebshi, E.A. \& Biacs, P.A. (1996): Antioxidant vitamin content of spice red pepper (paprika) as affected by technological and varietal factors. Food Chem., 55, 365-372.

Hungarian Standard (2010): Füszerpaprika (örlemény). Az összes természetes szinezöanyag-tartalom meghatározása (Ground (powdered) paprika. Determination of total natural colouring matter content), MSZ EN ISO 7541:2010, 6 pages.

LABuZA, T.P. (1984): Application of chemical kinetics to deterioration of foods. J. Chem. Educ., 61, 348-358. 
LabuzA, T.P. \& Kamman, J. (1983): Reaction kinetics and accelerated tests simulation as a function of temperature. -in: SAGuY, I. (Ed.) Applications of computers in food research, Marcel Dekker, New York. Chapter 4.

Malchev, E., Loncheva, N., Tanchev, S. \& Kalpakchieva, K. (1982): Quantitative changes in carotenoids during the storage of dried red pepper. Nahrung, 26, 415-420.

Márkus, F., Dadod, H.G., Kapitany, J. \& Biacs, P.A. (1999): Change in the carotenoid and antioxidant content of spice red pepper (paprika) as a function of ripening and some technological factors. J. Agr. Food Chem., 47, $100-107$.

Márkus, F. \& Kapitány, J. (2001): A füszerpaprika termesztése és feldolgozása (Cultivation and processing of spice red pepper): Mezőgazdasági Szaktudás Kiadó, Budapest, 112 pages.

Minguez-Mosquera, M.I. \& Honero-Méndez, D. (1993): Separation and quantification of the carotenoid pigments in red peppers (Capsicum annuum L.), paprika, and oleoresin by reversed phase HPLC. J. Agr. Food Chem., $41,1616-1620$.

Minguez-Mosquera, M.I. \& Honero-Méndez, D. (1994a): Changes in carotenoid esterification during the fruit ripening of Capsicum annuum Cv Bola. J. Agr. Food Chem., 42, 640-644.

MingueZ-Mosquera, M.I. \& Honero-MÉNDEZ, D. (1994b): Comparative study of the effect of paprika processing on the carotenoids in peppers (Capsicum annuum) of the Bola and Agridulce varieties. J. Agr. Food Chem., 42, $1555-1560$.

RoBerTson, G.L. (2007): Shelf life of packaged foods: its measurement and estimation. -in: BROdY, A.L. \& LoRD, J.B. (Eds) Developing new food products for a changing marketplace. $2^{\text {nd }}$ ed., CRC, Boca Raton - New York, pp. 465-490.

SAGUY, I. \& KAREL, M. (1980): Modeling of quality deterioration during food processing and storage. Food Technol., $34,78-85$

Somos, A. (1984): The paprika. Akadémiai Kiadó, Budapest. Chapter 2. pp. 49-98.

TAOUKIS, P.S., LabuZA, T.P. \& SAGUY, I.S. (1997): Kinetics of food deterioration and shelf-life prediction. -in: Valentas, K.J., Rotstein, E. \& Singh, R.P. (Eds). The handbook of food engineering practice. CRC Press Boca Raton - New York, p. 369. 